Article

\title{
Impacts of Chosen Parameters on Fe-Dependent Nitrate Reduction in Anammox Consortia: Performance and Bioactivity
}

\author{
Zhen $\mathrm{Bi}^{1,2, *}$, Yong Huang ${ }^{1,2}$, Wenjing Zhang ${ }^{1}$ and Ge Song ${ }^{1}$ \\ 1 School of Environment Science and Engineering, Suzhou University of Science and Technology, \\ Suzhou 215009, China; yhuang@mail.usts.edu.cn (Y.H.); wenjingzhangzwj@163.com (W.Z.); \\ songg1125@163.com (G.S.) \\ 2 National and Local Joint Engineering Laboratory for Municipal Sewage Resource Utilization Technology, \\ Suzhou 215009, China \\ * Correspondence: nljelab@mail.usts.edu.cn; Tel.: +86-0512-68786192
}

Received: 26 April 2020; Accepted: 11 May 2020; Published: 13 May 2020

check for updates

\begin{abstract}
Fe-dependent nitrate reduction by anammox consortia could serve as a valuable autotrophic denitrification process for wastewater treatment. However, influences of temperature, $\mathrm{pH}$, and $\mathrm{Fe} / \mathrm{NO}_{3}-\mathrm{N}$ ratio on this biochemical process have not been studied. The present study investigated individual and interactive effects of aforementioned parameters on nitrate removal performance and bioactivity of anammox consortia via a series of batch assays. Enzymes activity of nitrate reductase (NAR) and hydrazine dehydrogenase (HDH) of anammox consortia had high consistency with nitrogen removal performance and significantly depended on temperature and $\mathrm{Fe} / \mathrm{NO}_{3}-\mathrm{N}$ ratio, while the nar $G$ and $h d h$ genes expression were drastically depressed by extreme temperature. Models developed by response surface methodology (RSM) showed the significance of individual parameter followed by $\mathrm{Fe} / \mathrm{NO}_{3}-\mathrm{N}$ ratio $>$ temperature $>\mathrm{pH}$, while combined effects of temperature versus $\mathrm{Fe} / \mathrm{NO}_{3}-\mathrm{N}$ ratio exerted the most significant impacts. The $\mathrm{pH}$ in range of 4.0-8.0 had less influence. The optimum condition for nitrate removal efficiency (NRE) $>90 \%$ and total nitrogen removal efficiency (TNRE) $>75 \%$ was $4.0-7.4$ for $\mathrm{pH}, 25.5-30.0^{\circ} \mathrm{C}$ for temperature, and 31-48 for $\mathrm{Fe} / \mathrm{NO}_{3}-\mathrm{N}$ molar ratio. The maximum NRE and TNRE could be $98.68 \%$ and $79.42 \%$, respectively, under the condition of $\mathrm{pH}=4.00$, temperature $=28.5^{\circ} \mathrm{C}$ and $\mathrm{Fe} / \mathrm{NO}_{3}-\mathrm{N}$ ratio $=37.4$. The models showed good dependability for simulation nitrogen removal performance by anammox in the real semiconductor wastewater.
\end{abstract}

Keywords: anammox; nitrogen removal; Fe-dependent nitrate reduction; temperature and $\mathrm{Fe} / \mathrm{NO}_{3}-\mathrm{N}$ ratio; enzyme activity; gene expression

\section{Introduction}

Fe-dependent nitrate reduction is a biological process under anoxic condition, by which $\mathrm{Fe} / \mathrm{Fe}^{2+}$ served as electron donor for nitrate reduction [1]. Compared with traditional heterotrophic denitrification, Fe-dependent nitrate reduction processes advantages and competitiveness in consumption of organic carbon source and production of excess sludge, which has been paid much more attention by researchers [2-4]. Interestingly, the ability of nitrate reduction coupled with $\mathrm{Fe}^{2+}$ oxidation has been discovered in anammox bacteria [5,6]. In a previous study, we observed that anammox consortia showed a stable nitrate removal performance during long-term nitrate-feeding cultivation, and proposed they could gain ammonium and nitrite via Fe-dependent nitrate reduction to survive under nutrient-limit condition [7]. Previous publications illustrated the potential application of 
anammox for nitrate-containing wastewater treatment. However, the effects of environmental factors on this process are still lacking.

The majority of studies investigated Fe-dependent nitrate reduction focused on the nitrate removal performance. In the biological wastewater treatment process, temperature and $\mathrm{pH}$ are primary parameters, which have impacts on both system performance and bioactivity. For most microbial-mediated processes, temperature and $\mathrm{pH}$ are vital environmental parameters, which significantly determine the growth and metabolism of microorganisms. Generally, it is widely considered that the optimum temperature for most species of environmental engineering bacteria, including anammox bacteria, should be in a moderate range $[8,9]$. The Fe and nitrate as the electron acceptor and donor, the molar ratio of $\mathrm{Fe} / \mathrm{NO}_{3}-\mathrm{N}$, is also a key factor, which significantly affected the abiotic nitrate reduction and bioactivity. In different publications, the temperature ranged between $15^{\circ} \mathrm{C}$ and $45^{\circ} \mathrm{C}$ and a feed $\mathrm{pH}$ was from 6.0 to 8.0 [10]. $\mathrm{FeCl}_{2}$ or $\mathrm{FeSO}_{4}$ was usually supplemented as an iron source, and the average concentration of $\mathrm{NO}_{3}{ }^{-}$and $\mathrm{Fe}^{2+}$ was $0.1-6.0 \mathrm{mM}$ and $2.0-10.0 \mathrm{mM}$, respectively $[1,10,11]$. However, influence of these parameters on Fe-dependent nitrate reduction performance in the anammox system has not been studied so far. Microbial mediated nitrate reduction is catalyzed by nitrate reductase (Nar) encoded by the nar G gene [6], while anammox central metabolism relies on hydrazine dehydrogenase $(\mathrm{HDH})$ encoded by the $h d h$ gene [5]. Hitherto, less information is available on the relationship among nitrogen removal performance, enzymes activity, and functional gene expression under impacts of temperature, $\mathrm{pH}$, and $\mathrm{Fe} / \mathrm{NO}_{3}-\mathrm{N}$ ratio. To elucidate these issues will be beneficial for the application of anammox process, since nitrate is much more usual than nitrite in wastewater [7]. Moreover, about $11 \%$ of total nitrogen is inevitably converted to nitrate in the anammox process, thus, deteriorating the nitrogen removal performance [5].

Hence, in the present study, a series of short-term batch assays were conducted to provide fundamental information regarding the individual and combined effects of three parameters (temperature, $\mathrm{pH}$, and $\mathrm{Fe} / \mathrm{NO}_{3}-\mathrm{N}$ ratio) on nitrogen removal performance in nitrate-feeding anammox consortia. Meanwhile, the impacts of chosen parameters on key enzymes involving nitrate reduction and anammox central metabolism were elucidated. Finally, the optimal condition for desirable nitrogen removal performance was proposed as a model and the dependability of the model was verified by both synthetic and real wastewater.

\section{Materials and Methods}

\subsection{Synthetic Wastewater}

A basal nitrate medium, mainly consisting of $\mathrm{NaNO}_{3}(70 \mathrm{mg} \mathrm{N} / \mathrm{L})$ and other nutrients, was prepared according to the previous publications [12]. The $\mathrm{pH}$ of medium was adjusted by $0.5 \mathrm{M} \mathrm{HCl}$ or $1 \mathrm{M} \mathrm{NaOH}$ as needed. The medium was purged by $99.9 \% \mathrm{~N}_{2}$ gas for $15 \mathrm{~min}$ to exclude dissolved oxygen. Commercially produced nanoscale-Fe (n-Fe) powder $(50 \mathrm{~nm}, 98 \%$ purity) was pretreated to remove the oxide films covering the Fe surface [7], and then was added immediately to the serum bottles as needed.

To verify the validity of models for nitrate removal efficiency (NRE) and total nitrogen removal efficiency (TNRE) stimulation, the nitrate-containing wastewater produced by semiconductor process was obtained from a local polysilicon production plant. The major composition included $\mathrm{NO}_{3}-\mathrm{N}$ $(600 \pm 25 \mathrm{mg} / \mathrm{L}), \mathrm{NH}_{4}-\mathrm{N}(150 \pm 10 \mathrm{mg} / \mathrm{L})$, and fluorion $(500 \pm 15 \mathrm{mg} / \mathrm{L})$. The $\mathrm{pH}$ was $2.4 \pm 0.2$. The wastewater was diluted 10 times with deionized water before use, and $\mathrm{pH}$ was adjusted to 5.0 with $1 \mathrm{M} \mathrm{NaOH}$.

\subsection{Batch Assays Procedure}

Batch assays were proceeded in a series serum bottles with bulk volume of $120 \mathrm{~mL}$. Anammox sludge was taken from a stable lab-scale anammox reactor with nitrogen loading of $2 \mathrm{~kg}-\mathrm{N} / \mathrm{m}^{3} \cdot \mathrm{d}^{-1}$. Anammox bacteria of $K S U-1$ strain accounted for about $70-75 \%$ of the total biomass by FISH (fluorescence 
in situ hybridization) observation. The biomass was suspended in the serums with the same ratio of $10 \%(\mathrm{v} / \mathrm{v})$, and the biomass concentration was in range of 208-276 mg-volatile suspended solids per liter (VSS/L). All serum bottles were, thereafter, incubated in a temperature control shaker (DKZ-2B, Jinghong Laboratory Instrument Co., LTD, Shanghai, China) at $35^{\circ} \mathrm{C}$ and agitated at $150 \mathrm{rpm}$, with a strictly anaerobic condition for $60 \mathrm{~h}$. Medium samples were collected at the beginning and end of batch assays using syringes to determine the concentrations of ammonium, nitrite, and nitrate.

The $\mathrm{pH}$, temperature, and $\mathrm{Fe} / \mathrm{NO}_{3}-\mathrm{N}$ ratio were different in each test; detailed information was illustrated, where appropriate, within the section below. Different $\mathrm{Fe} / \mathrm{NO}_{3}-\mathrm{N}$ ratio was achieved by a different dosage of $n-F e$ powder. Each assay was conducted with three replications and the data were averaged.

\subsection{Determination of Enzymes Activity and Functional Genes Expression}

Nitrate reductase (Nar), encoded by the narG gene, mediates dissimilatory nitrate reduction to nitrite. Hydrazine dehydrogenase (HDH) encoded by the $h d h$ gene catalyzes hydrazine dehydrogenation and serves as the biomarker for anammox activity. Both gene expression and enzyme activity were determined to estimate the bioactivity with different experimental parameters. The procedure of enzyme activity measurement was described in Text S1. Each test for enzyme activity was conducted in triplicate.

The reverse transcription (RT)-qPCR was performed to detect the absolute and relative abundance of $n a r G$ and $h d h$ genes expression by using primer pairs showed in Table S1. The procedure was shown in Text S2, and each test was conducted in triplicate. The absolute abundance is calculated as copy numbers per gram of VSS, while the relative abundance represented the ratio between the measured copy numbers of each functional gene and the bacteria 16S rRNA gene (341F-518R).

\subsection{Response Surface Method (RSM) for Evaluating Individual and Interactive Effects of Parameters on Nitrate and Nitrogen Removal}

Effects of parameters feeding $\mathrm{pH}\left(\mathrm{X}_{1}\right)$, temperature $\left(\mathrm{X}_{2}\right)$, and $\mathrm{Fe} / \mathrm{NO}_{3}-\mathrm{N}$ ratio $\left(\mathrm{X}_{3}\right)$ on anammox consortia were determined statistically via RSM, based on batch experiments. For each of the parameters, a central coded value was taken, which was considered as 0 and estimated in different levels $(-1,0,+1)$ : $\mathrm{pH}(4,6,8)$, temperature $\left(15^{\circ} \mathrm{C}, 30^{\circ} \mathrm{C}, 45^{\circ} \mathrm{C}\right)$, and $\mathrm{Fe} / \mathrm{NO}_{3}-\mathrm{N}$ ratio $(2,26,50)$. In total, an experimental matrix including 17 batch assays was generated by Design Expert software (Stat Ease Inc. Minneapolis, MN, USA, version 8.0.7.1). As responses of nitrogen removal performance to aforementioned parameters and their interactions, nitrate removal efficiency (NRE) and total nitrogen removal efficiency (TNRE) were modeled as quadratic polynomials, as expressed as follows:

$$
\mathrm{Y}_{\mathrm{i}}=b_{0}+\sum b_{i} X_{i}+\sum b_{i j} X_{i} X_{j}+\sum b_{i i} X_{i}^{2}
$$

wherein the predicted response, $\mathrm{Y}_{\mathrm{i}}$ is NRE or TNRE; $b_{0}$, the constant; $X_{i}$ and $X_{j}$, aforementioned parameters; $b_{i}$, the linear coefficient; $b_{i i}$, the quadratic coefficients; $b_{i j}$, the interaction coefficient.

Analysis by ANOVA test was performed to reveal the influence that independent variables have on the regression model. The fitted equations were further expressed as three-dimensional (3D) plots to depict the interactions graphically. The fitting quality and statistical significance of polynomial model equations were analyzed. Both NRE and TNRE models were optimized via the regression models and, finally, both models were validated by using real semiconductor wastewater.

\subsection{Chemical Analysis}

The concentrations of ammonium, nitrite, nitrate, $\mathrm{Fe}^{2+}$, MLSS (mixed liquid suspended solids), and MLVSS (mixed liquid volatile suspended solids) were measured according to the Standard Methods [13]. pH and DO (disolved oxygen) were detected by digital meters, while the temperature was controlled by the water bath shaker (DKZ-2B, Jinghong Laboratory Instrument Co., LTD, Shanghai, 
China). TN, representing the total nitrogen in liquid phase, was the sum of ammonium, nitrite, and nitrate. Thus, the NRE and TNRE can be calculated by using the formulas of Equations (2) and (3), respectively:

$$
\begin{gathered}
\mathrm{NRE}=\left(\left(\text { Nitrate }_{\text {ini. }}-\text { Nitrate }_{\text {fin. }}\right) / \text { Nitrare }_{\text {ini. }}\right) \times 100 \% \\
\mathrm{TNRE}=\left(\left(\mathrm{TN}_{\text {ini. }}-\mathrm{TN}_{\text {fin. }}\right) / \mathrm{TN}_{\text {ini. }}\right) \times 100 \%
\end{gathered}
$$

where NRE/TNRE-nitrate/total nitrogen removal efficiency, $\%$; Nitrate $_{\text {ini. }} / \mathrm{Nitrate}_{\text {fin., }}$ initial/final nitrate concentration, $\mathrm{mg} \mathrm{N} / \mathrm{L} ; \mathrm{TN}_{\text {ini. }} / \mathrm{TN}_{\text {fin }}$ - - initial/final total nitrogen concentration, $\mathrm{mg} \mathrm{N} / \mathrm{L}$.

\section{Results}

\subsection{Performance, Enzyme Activity, and Genes Expression with Different Parameters}

Batch tests were carried out at various $\mathrm{pH}$, temperature, and $\mathrm{Fe} / \mathrm{NO}_{3}-\mathrm{N}$ levels based on the experimental matrix (Table 1). Discrepant nitrogen removal performance, enzymes activity, and genes transcriptional expression were investigated.

\begin{tabular}{|c|c|c|c|c|c|c|c|c|}
\hline $\begin{array}{l}\text { Batch } \\
\text { Test }\end{array}$ & $\mathrm{pH}$ & $\begin{array}{c}\text { Temp } \\
\left({ }^{\circ} \mathrm{C}\right)\end{array}$ & $\begin{array}{c}\mathrm{Fe} / \mathrm{NO}_{3}-\mathrm{N} \\
\text { Ratio }\end{array}$ & $\begin{array}{l}\text { n-Fe Powder } \\
\text { Dosage (g/L) }\end{array}$ & \multicolumn{2}{|c|}{ NRE (\%) } & \multicolumn{2}{|c|}{ TNRE (\%) } \\
\hline 2 & 8 & 15 & 26 & 7.28 & 51.2 & 52.52 & 39.42 & 34.17 \\
\hline 3 & 4 & 45 & 26 & 7.28 & 96.22 & 94.91 & 12.58 & 17.69 \\
\hline 4 & 8 & 45 & 26 & 7.28 & 90.05 & 88.37 & 13.37 & 14.29 \\
\hline 6 & 8 & 30 & 2 & 0.56 & 45.27 & 42.10 & 39.32 & 37.15 \\
\hline 7 & 4 & 30 & 50 & 14 & 91.51 & 94.72 & 81.82 & 73.86 \\
\hline 8 & 8 & 30 & 50 & 14 & 85.11 & 88.72 & 78.03 & 74.27 \\
\hline 9 & 6 & 15 & 2 & 0.56 & 9.00 & 10.86 & 8.96 & 6.31 \\
\hline 10 & 6 & 15 & 50 & 14 & 67.78 & 63.03 & 38.54 & 47.41 \\
\hline 14 & 6 & 30 & 26 & 7.28 & 88.07 & 88.54 & 69.81 & 71.82 \\
\hline 15 & 6 & 30 & 26 & 7.28 & 87 & 88.54 & 70.5 & 71.82 \\
\hline 16 & 6 & 30 & 26 & 7.28 & 91.09 & 88.54 & 78.03 & 71.82 \\
\hline 17 & 6 & 30 & 26 & 7.28 & 86 & 88.54 & 69.57 & 71.82 \\
\hline
\end{tabular}

Table 1. Experimental design and obtained results. NRE/TNRE—nitrate/total nitrogen removal efficiency.

The NRE was calculated based on reduction of nitrate concentration during experiments, while TNRE was obtained based on reduction of total nitrogen concentration. Thus, NRE was higher than TNRE in general. However, impacts of $\mathrm{pH}$, temperature, and $\mathrm{Fe} / \mathrm{NO}_{3}-\mathrm{N}$ values on $\mathrm{NRE}$ and TNRE were of inconsistency. The NRE and TNRE exhibited consistent levels for most batches; either of both being high or low. For example, the batch 7 ( $\mathrm{pH}=4.0$, temperature $=30{ }^{\circ} \mathrm{C}$ and $\mathrm{Fe} / \mathrm{NO}_{3}-\mathrm{N}$ ratio $\left.=50\right)$ gave the maximum value of TNRE $(81.82 \%)$, and a high value of NRE $(91.51 \%)$ simultaneously, and batch6 showed the lowest NRE and TNRE. However, four assays (batch 3, 4, 10 and 11) under $45^{\circ} \mathrm{C}$ showed striking differences between NRE and TNRE. Particularly, the TNRE of batch 3 was merely $12.58 \%$ while the NRE was around $96.22 \%$. The time course of nitrogen concentration revealed nitrate mostly converted to ammonium in these batch tests.

To elucidate the influence of temperature, $\mathrm{pH}$, and $\mathrm{Fe} / \mathrm{NO}_{3}-\mathrm{N}$ ratio on bioactivity, expression of functional genes narG and $h d h$ in mRNA level, and corresponding enzymes NAR and HDH activity were detected. As shown in Figure 1a, enzymes activity of NAR and HDH have high consistency with TNRE values. Batch assays that had relatively high TNRE always showed relatively high enzyme activity, i.e., batch 7, batch 8 , batch $13-17$, and vice versa. However, nar $G$ and $h d h$ expression were not completely consistent with corresponding enzymes activity as well as TNRE, as depicted 
in Figure 1b. For batch 5 and batch 6, narG and hdh abundance were in a high level, while the TNRE, NAR, and HDH activity were just in the middle in all batch tests. This discordance between enzyme activity and gene expression implied that transcriptional expression of genes was not always consistently matched enzymatic activity of proteins. Thus, elevated expression of the gene does not prove that the action of enzyme it is encoded in is taking place, actually. This standpoint was also in correlation with the previous publication [14]. Furthermore, it also can be found that temperature had a fundamental influence on $n a r G$ and $h d h$ expression, higher (i.e., $45^{\circ} \mathrm{C}$ ) or lower (i.e., $15^{\circ} \mathrm{C}$ ) temperature significantly depressed genes expression. NAR and HDH activity largely depended on temperature and $\mathrm{Fe} / \mathrm{NO}_{3}-\mathrm{N}$ ratio simultaneously. In contrast, $\mathrm{pH}$ in range of $4.0-8.0$ had less influence on bioactivity of anammox sludge.
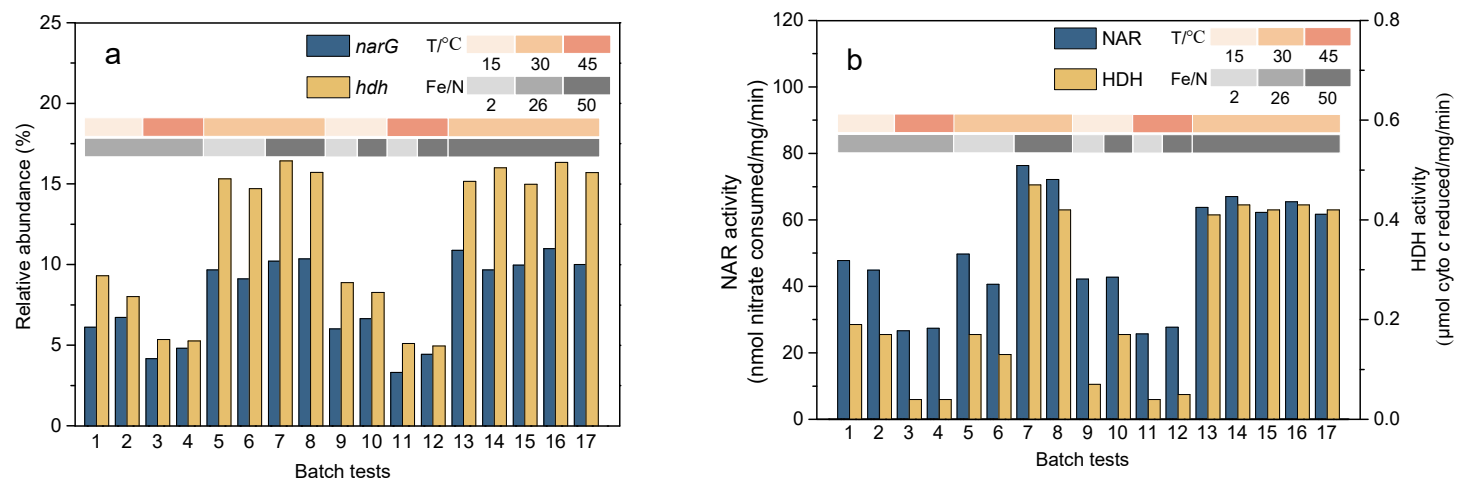

Figure 1. Genes nar $\mathrm{G} / \mathrm{hdh}$ abundance (a) and nitrate reductase (NAR)/hydrazine dehydrogenase (HDH) activity (b) in anammox consortia.

\subsection{Statistical Analysis}

On the basis of the batch results, quadratic polynomial equations containing temperature, $\mathrm{pH}$, and $\mathrm{Fe} / \mathrm{NO}_{3}-\mathrm{N}$ ratio were given to explain the responses of NRE and TNRE to variations of each parameter:

$$
\begin{gathered}
Y_{\text {NRE }}(\%)=-11.08-6.80 \mathrm{X}_{1}+4.07 \mathrm{X}_{2}+2.86 \mathrm{X}_{3}+0.07 \mathrm{X}_{1} \mathrm{X}_{2}+0.05 \mathrm{X}_{1} \mathrm{X}_{3}-0.0005 \mathrm{X}_{2} \mathrm{X}_{3}+ \\
0.05 \mathrm{X}_{1}^{2}-0.05 \mathrm{X}_{2}^{2}-0.04 \mathrm{X}_{3}^{2} \\
\mathrm{Y}_{\mathrm{TNRE}}(\%)=-85.02-7.17 \mathrm{X}_{1}+11.01 \mathrm{X}_{2}+1.76 \mathrm{X}_{3}+0.07 \mathrm{X}_{1} \mathrm{X}_{2}+0.08 \mathrm{X}_{1} \mathrm{X}_{3}-0.02 \mathrm{X}_{2} \mathrm{X}_{3}+ \\
0.09 \mathrm{X}_{1}^{2}-0.20 \mathrm{X}_{2}{ }^{2}-0.02 \mathrm{X}_{3}{ }^{2}
\end{gathered}
$$

wherein, $\mathrm{Y}$ is the predicted response of NRE or TNRE. $\mathrm{X}_{1}, \mathrm{X}_{2}$, and $\mathrm{X}_{3}$ represent the $\mathrm{pH}$, temperature, and $\mathrm{Fe} / \mathrm{NO}_{3}-\mathrm{N}$ ratio, respectively. Both NRE and TNRE values were simulated by models, Equations (4) and (5) were of good fitness to experimental data (Figure 2).

Statistical analyses for NRE and TNRE models were conducted and the outcomes were shown in Table 2. The probability value $(p)$ reveals the significance of each independent variable and their interaction strength. In general, the $p$ value less than 0.05 indicates the significance of model term $[15,16]$. In regression models of NRE and TNRE, $p$ values were $<0.0001$ and 0.0002 , respectively, with a confidence interval of $95 \%$, which was much less than 0.05 . The $F$ values of 65.56 (for NRE) and 22.45 (for TNRE) demonstrated significance of these models presented as Equations (4) and (5). 

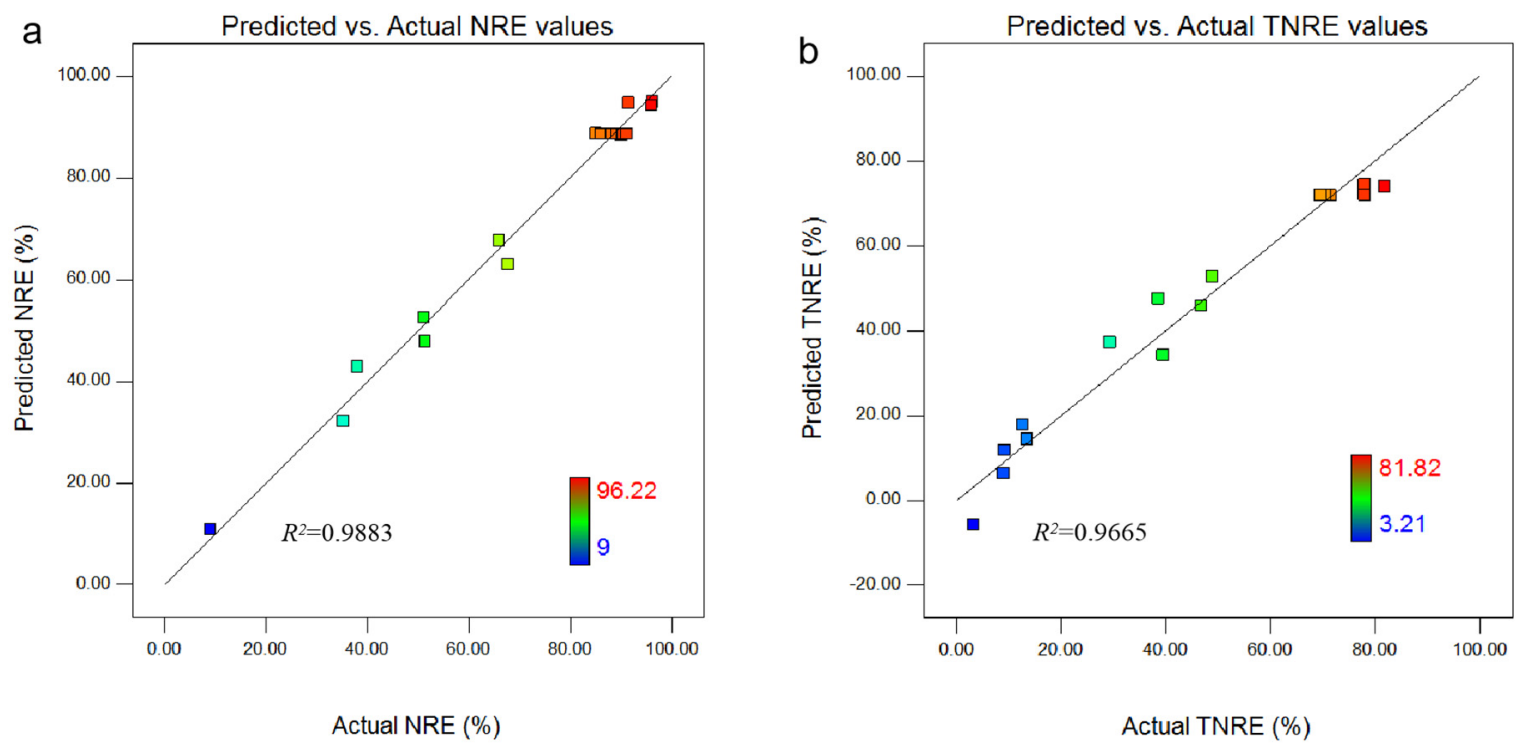

Figure 2. Stimulated versus experimental values of (a) NRE and (b) TNRE.

Squared value $\left(R^{2}\right)$ measures the extent of variability in NRE and TNRE that can be stimulated by the individual effect of $\mathrm{pH}$, temperature, and $\mathrm{NO}_{3}-\mathrm{N}$ ratio, as well as their interactive effects. In the present study, $R^{2}$ were 0.9883 for the NRE model and 0.9665 for the TNRE model, respectively, thus, a total variation of $98.83 \%$ in NRE and $96.65 \%$ in TNRE were attributed to the independent changes

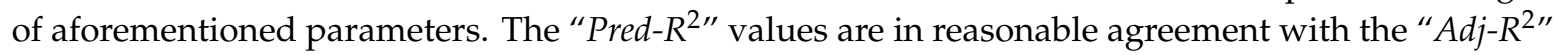
values, indicating the goodness of models, as shown in Table S2 (Supplementary materials). Moreover, the "Adequate Precision" revealing the parameter, which generated large signals in comparison to the noise, is defined as the signal-to-noise ratio. A ratio greater than 4 is recommended in previous publications $[17,18]$. The ratios of 25.75 (NRE) and 13.32 (TNRE) implied adequate signals of model stimulation in our study (Table S2). Hence, both models can be used to navigate the design space.

Overall, the statistical analyses illustrated the good fitness of models for NRE and TNRE stimulation. Thus, variations of NRE and TNRE responding to changes of temperature, $\mathrm{pH}$, and $\mathrm{Fe} / \mathrm{NO}_{3}-\mathrm{N}$ ratio can be reasonable explained by formula Equations (4) and (5).

Table 2. The least squares fit and the parameter estimates.

\begin{tabular}{ccccccccc}
\hline \multirow{2}{*}{ Term } & \multicolumn{2}{c}{ Sum of Squares (S.S.) } & \multicolumn{2}{c}{ Mean Square (M.S.) } & \multicolumn{2}{c}{$F$ Value } & \multicolumn{2}{c}{$p$-Value (Prob $>\boldsymbol{F}$ ) } \\
\cline { 2 - 9 } & S.S.NRE & S.S.TNRE & M.S.NRE & S.S.TNRE & $\boldsymbol{F}_{\text {NRE }}$ & $\boldsymbol{F}_{\text {TNRE }}$ & $p_{\text {NRE }}$ & $p_{\text {TNRE }}$ \\
\hline Model & $10,688.23$ & $12,401.79$ & 1187.58 & 1377.98 & 65.56 & 22.45 & $<0.0001$ & 0.0002 \\
$\mathrm{X}_{1}$-pH & 235.12 & 112.35 & 235.12 & 112.35 & 12.98 & 1.83 & 0.0087 & 0.2182 \\
$\mathrm{X}_{2}$-Temperature & 1996.17 & 1139.79 & 1996.17 & 1139.79 & 110.19 & 18.57 & $<0.0001$ & 0.0035 \\
$\mathrm{X}_{3}$-Fe/NO NO $_{3}$-N ratio & 5346.81 & 1713.17 & 5346.81 & 1713.17 & 295.16 & 27.91 & $<0.0001$ & 0.0011 \\
$\mathrm{X}_{1} \mathrm{X}_{2}$ & 18.40 & 16.73 & 18.40 & 16.73 & 1.02 & 0.27 & 0.3470 & 0.6178 \\
$\mathrm{X}_{1} \mathrm{X}_{3}$ & 23.28 & 62.41 & 23.28 & 62.41 & 1.29 & 1.02 & 0.2943 & 0.3469 \\
$\mathrm{X}_{2} \mathrm{X}_{3}$ & 0.15 & 140.54 & 0.15 & 140.54 & 0.008 & 2.29 & 0.3305 & 0.0740 \\
$\mathrm{X}_{1}{ }^{2}$ & 0.19 & 0.58 & 0.19 & 0.58 & 0.010 & 0.009 & 0.9216 & 0.9256 \\
$\mathrm{X}_{2}{ }^{2}$ & 699.42 & 8226.88 & 699.42 & 8226.88 & 38.61 & 134.01 & 0.0004 & $<0.0001$ \\
$\mathrm{X}_{3}{ }^{2}$ & 2215.96 & 682.09 & 2215.96 & 682.09 & 122.33 & 11.11 & $<0.0001$ & 0.0125 \\
\hline
\end{tabular}

3.3. Discrepant Effects of Temperature, $\mathrm{pH}$, and $\mathrm{Fe} / \mathrm{NO}_{3}-\mathrm{N}$ Ratio on NRE and TNRE

\subsubsection{Individual Effects}

Based on model analysis for NRE, linear coefficients of temperature, $\mathrm{pH}$, and $\mathrm{Fe} / \mathrm{NO}_{3}-\mathrm{N}$ ratio were vitally significant with the $p$ values less than 0.005 . Quadratic coefficients of temperature and $\mathrm{Fe} / \mathrm{NO}_{3}-\mathrm{N}$ ratio are also significant terms for NRE model. In case of TNRE, the liner and quadratic 
coefficients of temperature and $\mathrm{Fe} / \mathrm{NO}_{3}-\mathrm{N}$ ratio influenced the model significantly with the $p$ values of less than 0.005 . However, the $\mathrm{pH}$ did not exert significant effect on TNRE. This result is consistent with the phenomenon observed in batch assays (Figure $1 \mathrm{~b}$ ), in which $\mathrm{Fe} / \mathrm{NO}_{3}-\mathrm{N}$ ratio and temperature had fundamental influence on narG and hdh expression, NAR, and HDH activity, whereas $\mathrm{pH}$ in range of 4.0-8.0 had less influence on bioactivity of anammox sludge.

Based on results of statistical analyses and enzyme activity tests, the individual effect of aforementioned parameters can be sorted as $\mathrm{Fe} / \mathrm{NO}_{3}-\mathrm{N}$ ratio $>$ temperature $>$ initial $\mathrm{pH}$.

\subsubsection{Interactive Effects}

According to interactive coefficients in Table 2, the interactions of temperature, $\mathrm{pH}$, and Fe/ $\mathrm{NO}_{3}-\mathrm{N}$ ratio influenced NRE and TNRE in different extents. The positive values of $b_{2}, b_{3}, b_{12}$, and $b_{13}$ implied positive influence of corresponding parameters on NRE and TNRE. Moreover, 3D response surface graphs were generated and plotted to evaluate interaction effects of pairwise parameters on NRE and TNRE.

In general, the interactive effects of temperature combined with $\mathrm{pH}$ on NRE and TNRE were markedly different, as shown in Figure 3. Feeding $\mathrm{pH}$ values in range of 4.0-8.0 had insignificant effects on NRE and TNRE, while a different trend was obtained with temperature increasing. The NRE increased substantially when temperature increased from $15^{\circ} \mathrm{C}$ to $45^{\circ} \mathrm{C}$ while TNRE increased and then decreased with increasing temperature with $\mathrm{pH}$ ranging of 4.0-8.0. The TNRE exceeded 70\% within $33.5-21.5^{\circ} \mathrm{C}$, when $\mathrm{pH}$ was lower than 7.4, indicating an optimal condition for anammox consortia. Furthermore, the NRE showed an increasing and then decreasing trend, with temperature increasing when $\mathrm{pH}$ was higher than 6.9. Temperature is, thus, one of the control parameters of Fe-dependent nitrate reduction by anammox consortia.
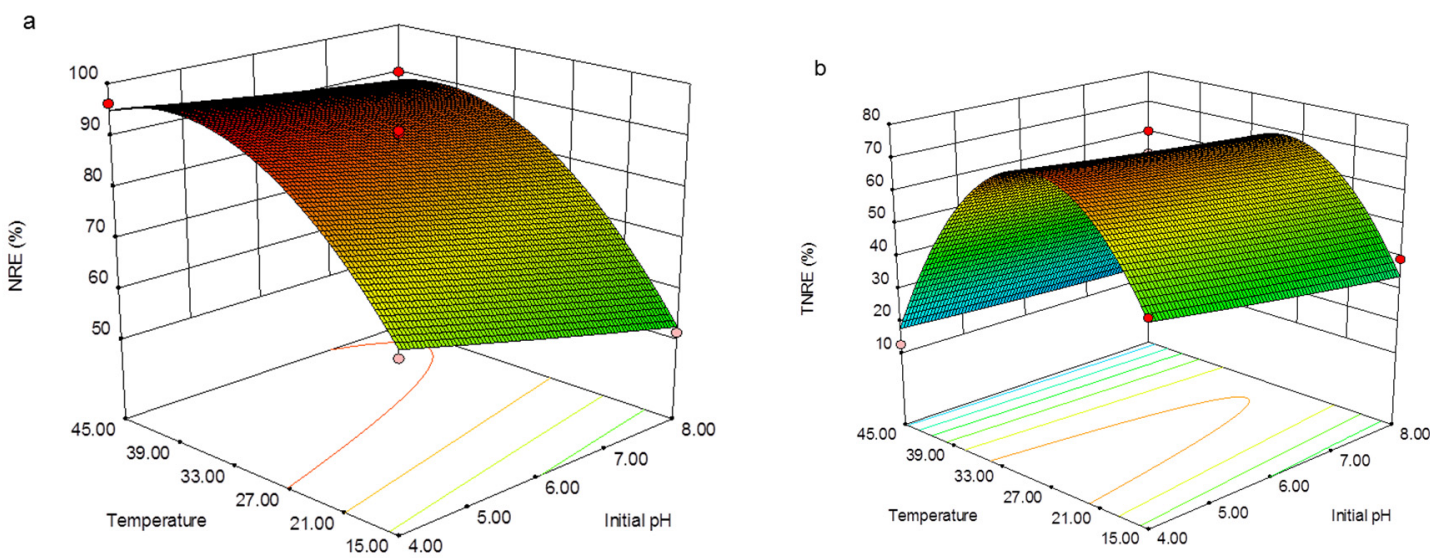

Figure 3. Response three-dimensional (3D)-surface plot of (a) NRE and (b) TNRE at different temperature versus initial $\mathrm{pH}$.

The response surface plots of NRE and TNRE generated by varying the levels of initial $\mathrm{pH}$ and $\mathrm{Fe} / \mathrm{NO}_{3}-\mathrm{N}$ ratio at a constant temperature of $30{ }^{\circ} \mathrm{C}$ were shown in Figure 4 . The NRE increased substantially with increasing $\mathrm{Fe} / \mathrm{NO}_{3}-\mathrm{N}$ ratio for a $\mathrm{pH}$ of $4.0-8.0$, and exceeded $80 \%$ when $\mathrm{Fe} / \mathrm{NO}_{3}-\mathrm{N}$ ratio over 20. However, a slightly decreasing trend in NRE was obtained when $\mathrm{pH}$ increased. The similar trend was observed in Figure 4b, in which the TNRE could exceed 70\% with Fe/ $\mathrm{NO}_{3}-\mathrm{N}$ ratio over 28. Therefore, $\mathrm{Fe} / \mathrm{NO}_{3}-\mathrm{N}$ ratio is a more critical parameter, which strongly affects the NRE and TNRE. 

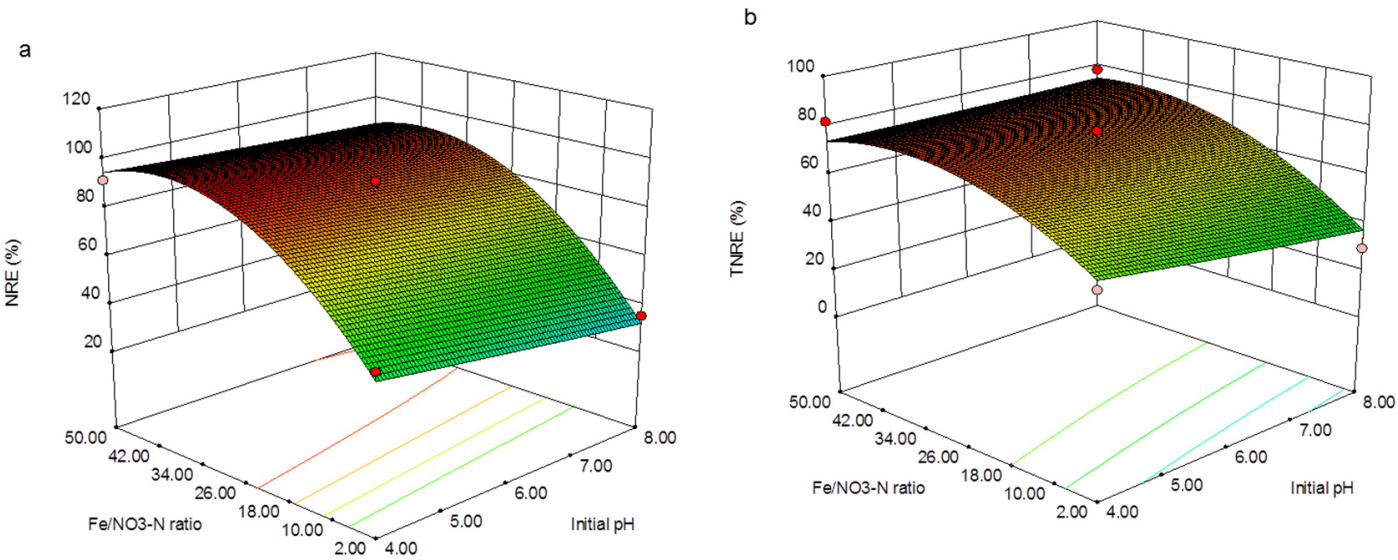

Figure 4. Response 3D-surface plot of (a) NRE and (b) TNRE at different $\mathrm{Fe} / \mathrm{NO}_{3}-\mathrm{N}$ ratio versus initial $\mathrm{pH}$.

Combined effects of temperature and $\mathrm{Fe} / \mathrm{NO}_{3}-\mathrm{N}$ ratio on NRE and TNRE are shown in Figure 5. The NRE elevated significantly with increasing temperature and $\mathrm{Fe} / \mathrm{NO}_{3}-\mathrm{N}$ ratio. The TNRE showed an increasing trend with elevated $\mathrm{Fe} / \mathrm{NO}_{3}-\mathrm{N}$ ratio at a constant temperature, but a different tendency appeared as temperature increased. The TNRE $>70 \%$ could be obtained with $\mathrm{Fe} / \mathrm{NO}_{3}-\mathrm{N}$ ratio of 22-59 when temperature of $21-33{ }^{\circ} \mathrm{C}$. Exceeding temperature dramatically decreased TNRE due to deteriorated bioactivity of anammox sludge under high temperature. Furthermore, exceeding $\mathrm{Fe} / \mathrm{NO}_{3}-\mathrm{N}$ ratio could result in a slight down trend in both NRE and TNRE.
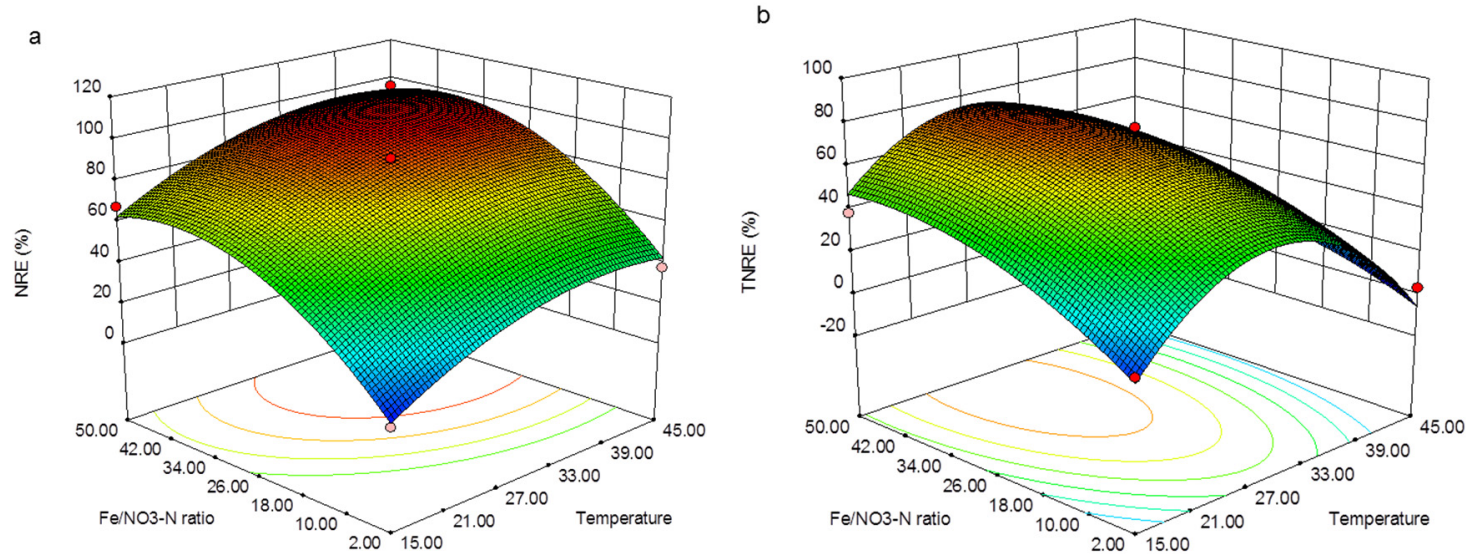

Figure 5. Response 3D-surface plots of (a) NRE and (b) TNRE at different $\mathrm{Fe} / \mathrm{NO}_{3}-\mathrm{N}$ ratio versus temperature.

\subsection{Model Optimization and Verification}

The optimization of NRE and TNRE was implemented using the software of Design Expert (Figure 6). Regions which simultaneously met the criteria of NRE $>90 \%$ and TNRE $>75 \%$ were identified, since these two criteria were chosen as the representation of desirable efficient nitrate reduction and nitrogen removal performance. 

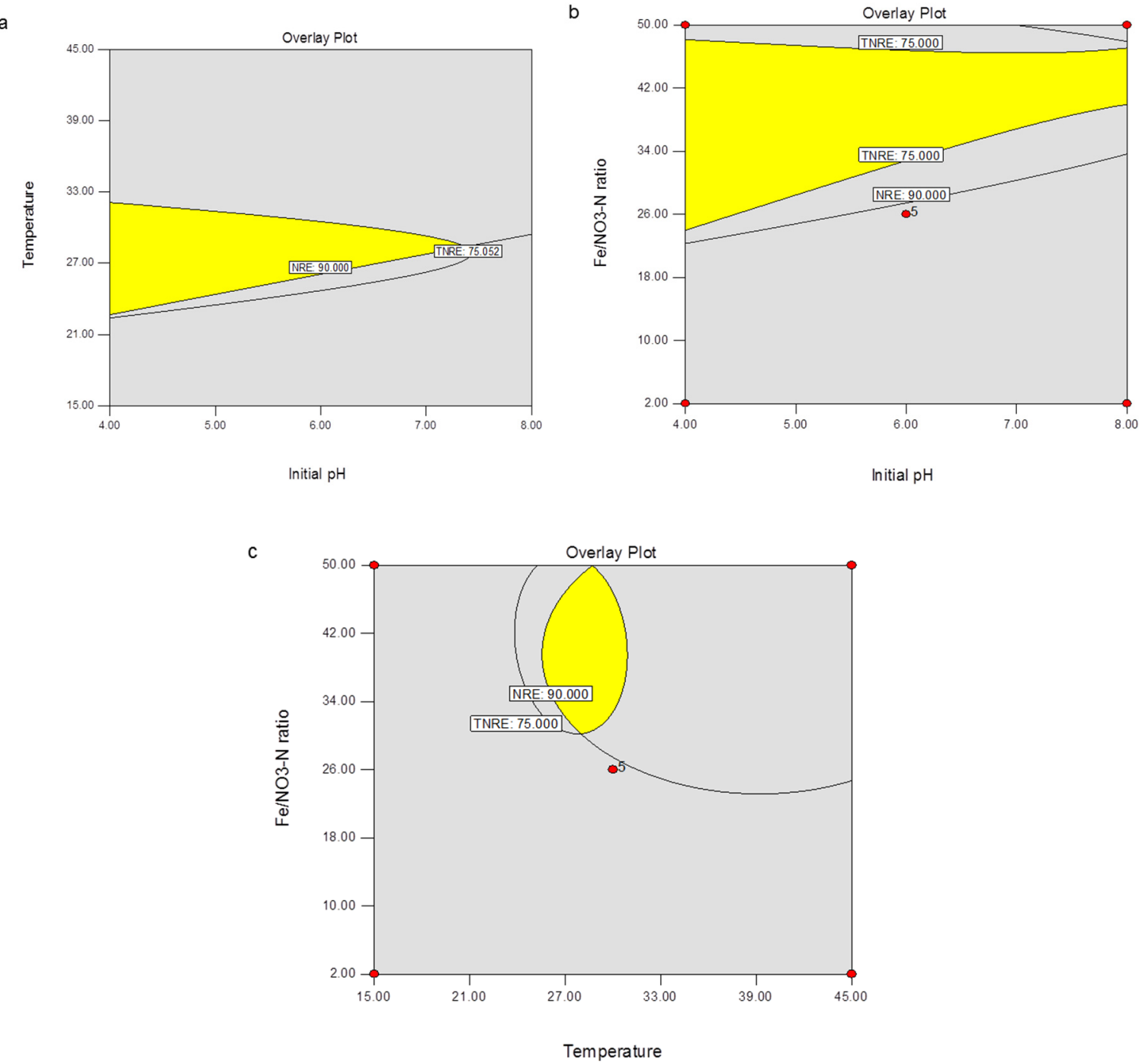

Figure 6. Overlay plot for the optimal region identified based on interactive influence of (a) pH versus temperature (constant $\mathrm{Fe} / \mathrm{NO}_{3}-\mathrm{N}$ of 26 ); (b) $\mathrm{pH}$ versus $\mathrm{Fe} / \mathrm{NO}_{3}-\mathrm{N}$ (constant temperature of $30{ }^{\circ} \mathrm{C}$ ); (c) temperature versus $\mathrm{Fe} / \mathrm{NO}_{3}-\mathrm{N}$ (constant $\mathrm{pH}$ of 6.0).

As depicted in Figure 6, the yellow shaded region defines permissible values of $\mathrm{pH}$, temperature and $\mathrm{Fe} / \mathrm{NO}_{3}-\mathrm{N}$ ratio to meet criteria of $\mathrm{NRE}>90 \%$ and TNRE $>75 \%$ simultaneously. The optimal range of each variable should be a $\mathrm{pH}$ of 4.0-7.4, temperature of $25.5-30.0{ }^{\circ} \mathrm{C}$, and $\mathrm{Fe} / \mathrm{NO}_{3}-\mathrm{N}$ ratio of 31-48. Specifically, the maximum NRE and TNRE could be $98.68 \%$ and $79.42 \%$, respectively, under the condition of $\mathrm{pH}=4.00$, temperature $=28.5^{\circ} \mathrm{C}$, and $\mathrm{Fe} / \mathrm{NO}_{3}-\mathrm{N}$ ratio $=37.4$.

In order to confirm the validity of models, four tests with different parameters were conducted to compare the experimental values of NRE and TNRE with the predicted values. Test 1 was carried out under the condition of initial $\mathrm{pH}(6.0)$, temperature $\left(28^{\circ} \mathrm{C}\right)$, and $\mathrm{Fe} / \mathrm{NO}_{3}-\mathrm{N}$ ratio (35) within the optimum region. Test 2 corresponded to the conditions of initial $\mathrm{pH}$ (5.0), maximum temperature $\left(30{ }^{\circ} \mathrm{C}\right)$, and $\mathrm{Fe} / \mathrm{NO}_{3}-\mathrm{N}$ ratio $(48)$, which was selected as the intersection points from the overlay graph. Test 3 was carried out under condition outside of the optimum region, with initial $\mathrm{pH}(8.0)$, temperature $\left(35^{\circ} \mathrm{C}\right)$, and $\mathrm{Fe} / \mathrm{NO}_{3}-\mathrm{N}$ ratio $(20)$. Test 4 was carried out by using semiconductor wastewater containing nitrate under room temperature of $22{ }^{\circ} \mathrm{C}$, with $\mathrm{pH}$ of 5.0 and $\mathrm{Fe} \mathrm{Fe} / \mathrm{NO}_{3}-\mathrm{N}$ ratio of 30 . All tests were conducted in triplicate, and results were shown in Table 3. In Test 1-3, the experimental values obtained from batch tests were close to those predicted by using the RSM. For Test 4, the NRE and TNRE predicted by using the RSM were $86.53 \%$ and $72.29 \%$, respectively, which were slightly higher than those detected in experiments. The possible explanation is that high concentration of fluorion 
affected the metabolic activity of anammox consortia, which resulted in a tiny discrepancy between simulation and experiment. In general, the RSM simulation should be an appropriate method for optimizing the Fe-dependent nitrate reduction process in anammox sludge.

Table 3. Verification experiments at different conditions.

\begin{tabular}{|c|c|c|c|c|c|c|c|}
\hline \multirow{2}{*}{ Test } & \multirow{2}{*}{$\mathrm{pH}$} & \multirow{2}{*}{ Temp. $\left({ }^{\circ} \mathrm{C}\right)$} & \multirow{2}{*}{$\mathrm{Fe} / \mathrm{NO}_{3}-\mathrm{N}$ Ratio } & \multicolumn{2}{|c|}{ NRE (\%) } & \multicolumn{2}{|c|}{ TNRE (\%) } \\
\hline & & & & Experim & Predicted & Experim & redicted \\
\hline 1 & 6.0 & 28 & 35 & 92.37 & 92.70 & 77.48 & 76.61 \\
\hline 2 & 5.0 & 30 & 48 & 88.46 & 94.667 & 79.36 & 74.67 \\
\hline 3 & 8.0 & 35 & 20 & 77.95 & 79.38 & 52.91 & 55.28 \\
\hline 4 & 4.0 & 22 & 30 & 80.65 & 86.53 & 67.27 & 72.29 \\
\hline
\end{tabular}

\section{Discussion}

In Fe-dependent nitrate reduction system, nitrate is the sole nitrogen substrate for anammox consortia. As obtained from batch assays, a high NRE is necessary but not sufficient for high TNRE, some assays, thus, showed significant difference between NRE and TNRE. The positive correlation between TNRE and enzyme activity revealed that TNRE was mainly attributed to biotic activity of anammox sludge, since abiotic reduction of nitrate by Fe produced ammonium rather than nitrogen gas $[7,19]$. The NRE was largely attributed to abiotic nitrate reduction since it was not consistent with bioactivity. Therefore, the discrepancy between NRE and TNRE observed could reveal the contributions of biotic and abiotic conversions in anammox consortia. That was in line with our previous research, which proposed the biotic processes [7]. Therefore, impacts of temperature, $\mathrm{pH}$, and $\mathrm{Fe} / \mathrm{NO}_{3}-\mathrm{N}$ ratio on Fe-dependent nitrate reduction in anammox consortia must be discussed from abiotic and biotic perspectives.

For most microorganisms, temperature is one of the most vital environmental factors, which can determine their growth and metabolism [8,9]. It is widely considered the optimum temperature for most species of anammox bacteria should be $30-40{ }^{\circ} \mathrm{C}$, though the existence of anammox bacteria have been discovered in a wide range of ambient temperature [20-23]. In present study, temperature significantly influenced nitrogen removal performance, enzymes activity, and functional genes expression of anammox consortia. The interactive effects of temperature and $\mathrm{Fe} / \mathrm{NO}_{3}-\mathrm{N}$ ratio indicated that a TNRE $>70 \%$ could be obtained with $\mathrm{Fe} / \mathrm{NO}_{3}-\mathrm{N}$ ratio of $22-59$ when temperature of $21-33{ }^{\circ} \mathrm{C}$, which is much lower than the recommended temperature range of $30-40{ }^{\circ} \mathrm{C}$ for anammox bacteria. Our results lighted the potential of anammox-based process for treating nitrate-containing wastewater, especially at typical tropical temperatures in warm climate regions. However, as can be seen from Figure 1, exceeding temperatures $\left(45^{\circ} \mathrm{C}\right)$ decreased TNRE dramatically resulting from inhibition of NAR/HDH activity and genes expression. That was consistent with the previous publication, in which the author noticed the irreversible cell lysis followed by enzymatic activity damage under extreme temperature [21,24].

The molar ratio of $\mathrm{Fe} / \mathrm{NO}_{3}-\mathrm{N}$ is also a key factor, which significantly affected the abiotic nitrate reduction and bioactivity of anammox sludge. As demonstrated in Figures 4 and 5, appropriate increase dosage of Fe exerted a positive effect on the nitrate reduction and resulted in an elevated NRE value, which could be interpreted as an increase of contact area and active sites between Fe particles and nitrate. In parallel, biotic nitrogen removal was improved which was presented as increasing TNRE value (Figures 4 and 5), since more $\mathrm{Fe}^{2+}$ release from Fe corrosion is favor of microbial activity enhancement [25-27]. The previous publication noticed that the dosage of Fe largely depends on the adaptability and community structure of the microbes [28]. The molar ratio of $\mathrm{Fe}^{2+} / \mathrm{NO}_{3}-\mathrm{N}<5.0$ was considered as a recommended level depending on the microbial species in previous publications $[1,6,9]$, with an optimal $\mathrm{Fe} / \mathrm{NO}_{3}-\mathrm{N}$ ratio of $31-48$, correspondingly 8.7-13.4 g-Fe/L of dosage, was recommended in the present study based on overlay plots of models. This dosage was generally lower than that required in current soil remediation, groundwater, and wastewater treatments [2,4]. Thus, it is commercial attractive to apply Fe-dependent nitrate reduction 
by anammox sludge for nitrate-containing wastewater treatment. However, the present study also found that microbial activity can be inhibited by an exceeding Fe dosage, which is in line with previous publications [29-31].

The $\mathrm{pH}$ is widely considered as a very important factor affecting enzymatic activity of microbes and abiotic nitrate reduction by $\mathrm{Fe}$. Some investigations proposed that a very cautious $\mathrm{pH}$ range (6.4-6.7) was necessary for good performance of Fe-dependent nitrate reduction [32]. However, some publication recommended the $\mathrm{pH}$ should be over 7.0 for balance the acidity production in this process [33]. Present study showed an inconsistent result that feeding $\mathrm{pH}$ did not significantly affect the Fe-dependent nitrate reduction performance in anammox sludge. In a pH range of 4.0-8.0, TNRE, HDH and NAR activity, and corresponding functional genes expression were not sensitive to $\mathrm{pH}$ variation. This is possible because both anammox reaction and ZVI corrosion in water produce alkalinity (Equations (6) and (7)), which maintained a suitable $\mathrm{pH}$ condition for anammox consortia when feeding $\mathrm{pH}$ was mildly acidic. Although it has been found that a higher $\mathrm{pH}$ (over 8.0) might damage microorganism activity [34], in this study, a Fe dosage of $0.56-14 \mathrm{~g} / \mathrm{L}$ could provide the suitable $\mathrm{pH}$ condition for anammox consortia to avoid the activity suppression by an exceeding $\mathrm{pH}$.

$$
\begin{gathered}
\mathrm{Fe}^{0}+2 \mathrm{H}_{2} \mathrm{O} \rightarrow \mathrm{H}_{2}+\mathrm{Fe}^{2+}+2 \mathrm{OH}^{-} \\
\mathrm{NH}_{4}^{+}+1.32 \mathrm{NO}_{2}^{-}+0.066 \mathrm{HCO}_{3}^{-}+0.13 \mathrm{H}^{+} \rightarrow 1.02 \mathrm{~N}_{2}+0.26 \mathrm{NO}_{3}^{-}+0.066 \text { biomass }+2.03 \mathrm{H}_{2} \mathrm{O}
\end{gathered}
$$

In parallel, $\mathrm{pH}$ affects the abiotic nitrate reduction by Fe. At low $\mathrm{pH}$ condition, the iron corrosion and $\mathrm{Fe}^{2+}$ release can be accelerated [4]; that promoted the abiotic nitrate reduction and further improve the anammox activity [25-27]. The present study predicted a good nitrogen removal performance with a wide $\mathrm{pH}$ range of 4.0-7.4, which is in favor of applying the process of Fe-dependent nitrate reduction in anammox consortia.

\section{Conclusions}

Impacts of temperature, $\mathrm{pH}$, and $\mathrm{Fe} / \mathrm{NO}_{3}-\mathrm{N}$ ratio on Fe-dependent nitrate reduction in anammox consortia were evaluated based on performance and bioactivity. Models developed by response surface methodology (RSM) showed good dependability for simulation this biochemical process. The individual influence on NRE and TNRE followed the order of $\mathrm{Fe} / \mathrm{NO}_{3}-\mathrm{N}$ ratio $>$ temperature $>$ $\mathrm{pH}$, while interactive effects of temperature and $\mathrm{Fe} / \mathrm{NO}_{3}-\mathrm{N}$ ratio exerted the most significant impacts. Enzyme activity of NAR and HDH had high consistency with TNRE values, and were significantly influenced by temperature and $\mathrm{Fe} / \mathrm{NO}_{3}-\mathrm{N}$ ratio. Gene transcriptional expression of $n a r G$ and $h d h$ was depressed by extreme temperature. The optimum condition for NRE $>90 \%$ and TNRE $>$ $75 \%$ was: $4.0-7.4$ for initial $\mathrm{pH}, 25.5-30.0{ }^{\circ} \mathrm{C}$ for temperature, and $31-48$ for $\mathrm{Fe} / \mathrm{NO}_{3}-\mathrm{N}$ molar ratio. The maximum NRE and TNRE could be $98.68 \%$ and $79.42 \%$, respectively, under the condition of $\mathrm{pH}=4.00$, temperature $=28.5^{\circ} \mathrm{C}$, and $\mathrm{Fe} / \mathrm{NO}_{3}-\mathrm{N}$ ratio $=37.4$. The outcomes of the present study showed the potential of treatment of nitrate-containing wastewater via anammox-based technology, since the commercial $\mathrm{Fe}^{0}$ powder in different particle sizes can be obtained easily. Further studies are necessary to completely identify the enzymatic machinery that mediates reduction of nitrate in anammox consortia, at both metagenomic and metabolomic levels.

Supplementary Materials: The following are available online at http://www.mdpi.com/2073-4441/12/5/1379/s1, Text S1: Extraction and determination of NAR and HDH activity; Text S2: Total RNA extraction and reverse transcription (RT)-qPCR; Table S1: Primers used in RT-qPCR; Table S2: ANOVA for RSM of NRE and TNRE.

Author Contributions: Conceptualization, Z.B. and Y.H.; methodology, W.Z.; software, G.S.; formal analysis, G.S.; investigation, W.Z. and G.S.; data curation, W.Z.; writing-Z.B.; writing-review and editing, Z.B.; visualization, W.Z.; funding acquisition, Z.B. and Y.H. All authors have read and agreed to the published version of the manuscript.

Funding: This research was funded by the National Science Foundation of China, grant number 21607110 and 5193000487; and the National \& Local Joint Engineering Laboratory for Municipal Sewage Resource Utilization Technology, Suzhou University of Science and Technology, grant number 2018KF02). The APC was funded by National Science Foundation of China, grant number 21607110. 
Conflicts of Interest: The authors declare no conflict of interest. The funders had no role in the design of the study; in the collection, analyses, or interpretation of data; in the writing of the manuscript, or in the decision to publish the results.

\section{References}

1. Straub, K.L.; Benz, M.; Schink, B.; Widde, F. Anaerobic nitrate-dependent microbial oxidation of ferrous iron. Appl. Environ. Microb. 1996, 62, 1458-1460. [CrossRef]

2. Yan, W.; Lien, H.L.; Koel, B.E.; Zhang, W. Iron nanoparticles for environmental clean-up: Recent developments and future outlook. Environ. Sci. Process. Impacts 2013, 15, 63-77. [CrossRef] [PubMed]

3. Zhang, M.; Zheng, P.; Wang, R.; Li, W.; Lu, H.; Zhang, J. Nitrate-dependent anaerobic ferrous oxidation (NAFO) by denitrifying bacteria: A perspective autotrophic nitrogen pollution control technology. Chemosphere 2014, 117, 604-609. [CrossRef] [PubMed]

4. Sun, Y.; Li, J.; Huang, T.; Guan, X. The influences of iron characteristics, operating conditions and solution chemistry on contaminants removal by zero-valent iron: A review. Water Res. 2016, 100, 277-295. [CrossRef]

5. Strous, M.; Pelletier, E.; Mangenot, S.; Rattei, T.; Lehner, A.; Taylor, M.W.; Horn, M.; Daims, H.; Bartol-Mavel, D.; Wincker, P.; et al. Deciphering the evolution and metabolism of an anammox bacterium from a community genome. Nature 2006, 440, 790-794. [CrossRef]

6. Oshiki, M.; Ishii, S.; Yoshida, K.; Fujii, N.; Ishiguro, M.; Satoh, H. Nitrate-dependent ferrous iron oxidation by anaerobic ammonium oxidation (anammox) bacteria. Appl. Environ. Microb. 2013, 79, 4087-4093. [CrossRef]

7. Bi, Z.; Zhang, W.; Song, G.; Huang, Y. Iron-dependent nitrate reduction by anammox consortia in continuous-flow reactors: A novel prospective scheme for autotrophic nitrogen removal. Sci. Total Environ. 2019, 692, 582-588. [CrossRef]

8. Ma, B.; Wang, S.; Cao, S.; Miao, Y.; Jia, F.; Du, R.; Peng, Y. Biological nitrogen removal from sewage via anammox: Recent advances. Bioresour. Technol. 2016, 200, 981-990. [CrossRef]

9. Tomaszewski, M.; Cema, G.; Ziembińska-Buczyńska, A. Influence of temperature and $\mathrm{pH}$ on the anammox process: A review and meta-analysis. Chemosphere 2017, 182, 203-214. [CrossRef]

10. Kiskira, K.; Papirio, S.; Van Hullebusch, E.D.; Esposito, G. Fe(II)—Mediated autotrophic denitrification: A new bioprocess for iron bioprecipitation/biorecovery and simultaneous treatment of nitrate-containing wastewaters. Int. Biodeterior. Biodegr. 2016, 119, 631-648. [CrossRef]

11. Weber, K.A.; Pollock, J.; Cole, K.A.; O'Connor, S.M.; Achenbach, L.A.; Coates, J.D. Anaerobic nitrate-dependent iron (II) bio-oxidation by a novel lithoautotrophic betaproteobacterium, strain 2002. Appl. Environ. Microb. 2006, 72, 686-694. [CrossRef] [PubMed]

12. van de Graff, A.A.; De Bruijn, P.; Robertson, L.A.; Jetten, M.S.M.; Kuenen, J.G. Autotrophic growth of anaerobic ammonium-oxidizing micro-organisms in a fluidized bed reactor. Microbiology 1996, 142, 2187-2196. [CrossRef]

13. APHA. Standard Methods for the Examination of Water and Wastewater, 23rd ed.; American Public Health Association: Washington, DC, USA, 2017.

14. Chubukov, V.; Uhr, M.; Chat, L.L.; Kleijn, R.J.; Jules, M.; Link, H.; Aymerich, S.; Stelling, J.; Sauer, U. Transcriptional regulation is insufficient to explain substrate-induced flux changes in Bacillus subtilis. Mol. Syst. Biol. 2013, 9, 709-721. [CrossRef] [PubMed]

15. Yue, Z.B.; Yu, H.Q.; Harada, H.; Li, Y.Y. Optimization of anaerobic acidogenesis of an aquatic plant, Canna indica L., by rumen cultures. Water Res. 2007, 41, 2361-2370. [CrossRef] [PubMed]

16. Xing, B.S.; Guo, Q.; Zhang, Z.Z.; Zhang, J.; Wang, H.Z.; Jin, R.C. Optimization of process performance in a granule-based anaerobic ammonium oxidation (anammox) upflow anaerobic sludge blanket (uasb) reactor. Bioresour. Technol. 2014, 170, 404-412. [CrossRef]

17. Zinatizadeh, A.A.L.; Pirsaheb, M.; Bonakdari, H.; Younesi, H. Response surface analysis of effects of hydraulic retention time and influent feed concentration on performance of an UASFF bioreactor. Waste Manag. 2012, 30, 1798-1807. [CrossRef]

18. Moon, C.; Singh, R.; Chaganti, S.R.; Lalman, J.A. Modeling sulfate removal by inhibited mesophilic mixed anaerobic communities using a statistical approach. Water Res. 2013, 47, 2341-2351. [CrossRef] 
19. Shi, L.; Dong, H.; Reguera, G.; Beyenal, H.; Lu, A.; Liu, J.; Yu, H.Q.; Fredrickson, J.K. Extracellular electron transfer mechanisms between microorganisms and minerals. Nat. Rev. Microbiol. 2016, 14, 651-662. [CrossRef]

20. Strous, M.; Kuenen, J.G.J.; Jetten, M.S.M. Key physiology of anaerobic ammonium oxidation. Appl. Environ.'Microb. 1999, 65, 3248-3250. [CrossRef]

21. Dosta, J.; Fernández, I.; Vázquez-Padín, J.R.; Mosquera-Corral, A.; Campos, J.L.; Mata-álvarez, J. Short-and long-term effects of temperature on the anammox process. J. Hazard. Mater. 2008, 154, 688-693. [CrossRef]

22. Ali, M.; Okabe, S. Anammox-based technologies for nitrogen removal: Advances in process start-up and remaining issues. Chemosphere 2015, 141, 144-153. [CrossRef] [PubMed]

23. Ma, H.; Zhang, Y.; Xue, Y.; Zhang, Y.; Li, Y. Relationship of heme c, nitrogen loading capacity and temperature in anammox reactor. Sci. Total Environ. 2019, 659, 568-577. [CrossRef] [PubMed]

24. Zhu, G.; Peng, Y.; Li, B.; Guo, J.; Yang, Q.; Wan, S. Biological removal of nitrogen from wastewater. In Reviews of Environmental Contamination and Toxicology; Springer: New York, NY, USA, 2008; pp. 159-195.

25. Qiao, S.; Bi, Z.; Zhou, J.; Cheng, Y.; Zhang, J. Long term effects of divalent ferrous ion on the activity of anammox biomass. Bioresour. Technol. 2013, 142, 490-497. [CrossRef] [PubMed]

26. Bi, Z.; Qiao, S.; Zhou, J.; Tang, X.; Zhang, J. Fast start-up of anammox process with appropriate ferrous iron concentration. Bioresour. Technol. 2014, 170, 506-512. [CrossRef]

27. Ferousi, C.; Lindhoud, S.; Baymann, F.; Kartal, B.; Jetten, M.S.M.; Reiman, J. Iron assimilation and utilization in anaerobic ammonium oxidizing bacteria. Curr. Opin. Chem. Biol. 2017, 37, 129-136. [CrossRef]

28. You, G.; Wang, P.; Hou, J.; Wang, C.; Xu, Y.; Miao, L.; Lv, B.; Yang, Y.; Zhang, F. The use of zero-valent iron (ZVI)-microbe technology for wastewater treatment with special attention to the factors influencing performance: A critical review. Crit. Rev. Environ. Sci. Technol. 2017, 47, 877-907. [CrossRef]

29. Lavania, A.; Bose, P. Effect of metallic iron concentration on end-product distribution during metallic iron-assisted autotrophic denitrification. J. Environ. Eng. 2006, 132, 994-1000. [CrossRef]

30. Wu, D.; Zheng, S.; Ding, A. Performance of a zero valent iron-based anaerobic system in swine wastewater treatment. J. Hazard. Mater. 2015, 286, 1-6. [CrossRef]

31. Kong, X.; Wei, Y.; Xu, S.; Liu, J.; Li, H.; Liu, Y.; Yu, S. Inhibiting excessive acidification using zero-valent iron in anaerobic digestion of food waste at high organic load rates. Bioresour. Technol. 2016, 211, 65-71. [CrossRef]

32. Straub, K.L.; Schönhuber, W.A.; Buchholz-Cleven, B.E.; Schink, B. Diversity of ferrous iron-oxidizing, nitrate-reducing bacteria and their involvement in oxygen-independent iron cycling. Geomicrobiol. J. 2004, 21, 371-378. [CrossRef]

33. Zhang, Q.; Ji, F.; Xu, X. Optimization of nitrate removal from wastewater with a low $\mathrm{C} / \mathrm{N}$ ratio using solid-phase denitrification. Environ. Sci. Pollut. R. 2016, 23, 698-708. [CrossRef] [PubMed]

34. Guo, B.; Chen, Y.; Lv, L.; Ahmad, H.A.; Ni, S.; Ren, L.; Gui, Z.; Fang, X.; Qiao, Z.; Ding, S. Transformation of the zero valent iron dosage effect on anammox after long-term culture: From inhibition to promotion. Process Biochem. 2019, 78, 132-139. [CrossRef]

(C) 2020 by the authors. Licensee MDPI, Basel, Switzerland. This article is an open access article distributed under the terms and conditions of the Creative Commons Attribution (CC BY) license (http://creativecommons.org/licenses/by/4.0/). 